Article

\title{
Evolution as a Theological Research Program
}

\author{
Cornelius Hunter
}

check for updates

Citation: Hunter, Cornelius. 2021. Evolution as a Theological Research Program. Religions 12: 694. https://doi.org/10.3390/rel12090694

Academic Editor: Jeffery D. Long

Received: 13 July 2021

Accepted: 23 August 2021

Published: 30 August 2021

Publisher's Note: MDPI stays neutral with regard to jurisdictional claims in published maps and institutional affiliations.

Copyright: (C) 2021 by the author. Licensee MDPI, Basel, Switzerland. This article is an open access article distributed under the terms and conditions of the Creative Commons Attribution (CC BY) license (https:/ / creativecommons.org/licenses/by/ $4.0 /)$.
School of Natural and Applied Sciences, William Jessup University, Rocklin, CA 95765, USA; chunter@jessup.edu

\begin{abstract}
Charles Darwin's theory of evolution interacted with non-empirical factors including a range of theological concerns. The influence of these theological concerns is typically modeled as secondary to that of empirical evidence. In both Darwin's thought and later development of the theory of evolution, theological concerns have been viewed as serving in a range of possible roles. However, the theological concerns have consistently been viewed as, ultimately, subservient to empirical science. In the end, science has the final say regarding the content and evaluation of the theory. Here, this paper demonstrates the failure of this model. Theological concerns do have primacy over the science. They motivate the development of evolutionary theory, and they control the interpretation of the empirical evidence and justification of the theory. It is more accurate to view evolution as a theological research program.
\end{abstract}

Keywords: evolution; modern synthesis; utilitarianism

\section{Introduction}

Later in life, Charles Darwin recollected that "Many years ago I was strongly advised by a friend never to introduce anything about religion in my works." Darwin's point was that he did not mix religion into his scientific writings-a point with which Gertrude Himmelfarb concurred as she concluded, "It was only in his autobiography that Darwin gave free expression to his religious opinions." (Himmelfarb 1959, p. 383) This view is common amongst observers. As Stephen Dilley concluded, "Contemporary scholarship has established that Darwin held a firm commitment to leave aside God's activity as a properly scientific explanation for natural phenomena long before he penned the Origin." (Dilley 2013, p. 24)

This consensus view is, however, inconsistent with the historical record. Darwin did not leave aside God's activity, and in fact, theology played a foundational and determinative role in Darwin's theory development and justification. The first hint of theology's primacy in Darwin's theory of evolution is apparent in Darwin's early religious sentiments. As Section 2 demonstrates, Darwin's early influences, as well as his notebook entries, were opposed to miracles and an intervening creator. However, we do not need to rely on notebook entries for, as we shall see in Sections 3 and 4, theological claims are common in Darwin's On the Origin of Species (Darwin 1859), where they are essential to his science. The religion is not a tangential message, and one need not read between the lines to see it. In the Origin, it would not be an exaggeration to say the religion drives the science. Darwin's religion is not merely present, it is prominent and has primacy over the science. The religion is foundational.

The importance of religion in Darwin's theory is also apparent in the science he presented. As Section 5 shows, Darwin did not have sufficient scientific arguments and evidence to advance his theory. Finally, as Sections 6 and 7 demonstrate, these roles and relationships between religion and science persisted after Darwin. This religious foundation was by no means peculiar to Darwin's thought. It has remained foundational since Darwin in motivating and justifying the theory. What we find in Darwin continued in later evolutionary thought. Therefore, the thesis of this paper is that evolution is best understood as a theological research program. 
To defend this thesis, the next six sections demonstrate the failure of six different rebuttals (Table 1). The rebuttals are evaluated in their logical order. The six rebuttals, with section numbering, are:

Table 1. The failure of six different rebuttals.

\begin{tabular}{|c|c|}
\hline Section & Rebuttal \\
\hline 2 & Darwin's discovery of transmutation predated his religious views favoring it. \\
\hline 3 & Darwin's theological premises in the Origin did not play an epistemological role. \\
\hline 4 & Darwin was merely practicing reductio theology in the Origin. \\
\hline 5 & $\begin{array}{l}\text { In spite of epistemological assistance from theology, Darwin had epistemologically } \\
\text { sufficient scientific arguments and evidence. }\end{array}$ \\
\hline 6 & $\begin{array}{l}\text { In spite of its theological foundation, evolutionary science after Darwin had no such } \\
\text { metaphysical dependence. }\end{array}$ \\
\hline 7 & $\begin{array}{l}\text { Scientific shortcomings of the Origin were eventually remedied as evolution was } \\
\text { overwhelmingly proven by the later science. }\end{array}$ \\
\hline
\end{tabular}

As we will see, all of these rebuttals clearly fail. This raises important questions not only about the fundamental nature of evolutionary theory but about how it has been received and understood. I conclude that evolution is a theological research program in the sense that theological claims play a crucial role. These claims motivate and play an indispensable role in evolutionary theory.

For the purposes of this paper, I define as religious or theological those claims that predict divine action (e.g., what God would or would not do). With some exceptions, I generally do not trace these claims to their historical theological influences as this is not required to advance my thesis and would greatly lengthen the paper. This paper is narrowly focused on the theological content of evolutionary theory and its implications for the theory. The greater context concerning the history of the theology traditions and how they influenced origins thinking is beyond the scope of this paper.

\section{Darwin's Discovery of Transmutation Predates His Religious Views Favoring It}

Darwin's theology is sometimes seen as secondary to his science for the purported reason that he accepted and discovered the scientific hypotheses of the transmutation of species and natural selection, respectively, prior to the emergence of his religious views that were sympathetic and supportive of his theory of evolution. In other words, his science had primacy and priority over his religion. For example, John Reiss wrote that Darwin became critical of natural theology "only after he came to the theory of natural selection ..." (Reiss 2009, p. 142 emphasis in original) Similarly, Dov Ospovat explained that "Darwin's evolutionary speculations had forced him to reject teleological explanation." (Ospovat 1981, p. 33).

However, prior to his development of evolutionary theory, Darwin exhibited theological opinions in favor of a transcendent creator and a law-driven, naturalistic origin of species. Darwin certainly expressed (i) disdain for natural theology and (ii) a theological preference for transmutation prior to his discovery of natural selection in September 1838 . Discussing Darwin's years on the HMS "Beagle" voyage, 1831-36, Michael Ruse described Darwin as already having such theological commitments:

Darwin rejected miracles ... his theological commitment was to deism rather than to theism. He grew to accept an Unmoved Mover who works through unbroken law, rather than a God of intervention who works through miracles that break physical laws.... the greatness of God lay in his ability to plan everything beforehand and then just step back and watch it all unfurl as he intended. This was the God that Charles Darwin accepted. (Ruse 2003, pp. 95-96) 
After his return to England, Desmond and Moore documented how strong the sentiment was for Darwin and others in his social circle for a non-intervening creator. (Desmond and Moore 1991, p. 213ff) “Dining at Lyell's, dancing at Babbage's, he [Darwin] found the idea of miraculous, catastrophic interruptions increasingly deplored. The rule of law had to be upheld." (Desmond and Moore 1991, p. 218) Darwin expressed these religious ideas throughout his early notebooks, prior to September 1838, such as in this passage from Notebook D:

How far grander than idea from cramped imagination that God created (warring against those very laws he established in all organic nature) the Rhinoceros of Java \& Sumatra, that since the time of the Silurian he has made a long succession of vile molluscous animals. How beneath the dignity of him, who is supposed to have said let there be light \& there was light.- whom it has been declared "he said let there be light \& there was light"-bad taste. (Darwin 1838, pp. 36-37)

This entry indicates that for Darwin an intervening creator (warring against his own laws) was too suggestive of a deus ex machina, or God in the machine. Such intervention would be beneath the creator's dignity-a well-worn, widely used theological argument tracing back to such unlikely bedfellows as John Ray, for many the father of British natural theology, and the Epicureans. Darwin's conclusion to the matter ("bad taste") illustrates how this theological mandate for a law-driven, deistic creator had become culturally internalized. Worse than illogical, an intervening creator had become out of style.

Further, Darwin's son Frances indicated that Darwin believed in the transformation of species as early as 1832 (Mandelbaum 1958, p. 365n), a time when Darwin would have had even less scientific evidence to go on. As Frances explained, the evidence was "indirect." In his early years, Darwin had plenty of such "indirect" influences, including both from within his family (Desmond and Moore 1991, p. 6ff), with its influences from the deistic Joseph Priestley, and mentors at Edinburgh University such as the "savagely anti-Christian," "uncompromising evolutionist" Robert Grant. (Desmond and Moore 1991, p. p34ff) The various transformism ideas at Edinburgh, influenced by continental thought, provided Darwin with a general transformist principle rather than any useful scientific mechanisms. (Jenkins 2019)

Finally, Darwin gathered evidence during the "Beagle" voyage, such as at the Galapagos Islands, that typically is presented as important empirical support for his theory of evolution. However, as we shall see in Section 4, Darwin's interpretation of this evidence, once again, is theologically laden. (Hunter 2001, pp. 61-62) In summary, reconstructions that present the young Darwin as a theologically neutral observer who empirically arrives at evolutionary theory that subsequently impacts his theological views do not do justice to the complexities and entanglements between science and religion in Darwin's day and, in his thought, even in his younger years.

\section{Darwin's Theological Premises in the Origin Did Not Play an Epistemic Role}

Another common claim is that Darwin's theological passages in the Origin, while providing interesting insights and perhaps targeted at religious readers, did not play a role in Darwin's confirmation of his theory of evolution. In other words, the religion was an aside. This claim also does not hold up to scrutiny, and I begin with three representative religious claims in the Origin that reveal an epistemological role. I use Darwin's sixth edition, though the religious claims are a common thread throughout all the editions. My first example comes from the final summary section of Chapter 2. The first two chapters of Origin are on the topic of biological variation. The first chapter discusses what breeders had learned and the second chapter discusses biological variability in nature. It was almost fifty pages of relatively abstract, dense material, in which Darwin attempted to develop an important concept, namely, that the species we observe are, in fact, rather arbitrary. At a given point in time, the species may seem to be distinct, but over long time periods, the species are fluid, the boundaries between them shift, and new species emerge. However, after this long exposition of detailed biological facts, Darwin introduced his first major 
theological claim: the evidence contradicts the traditional view that the species were independently created:

In genera having more than the average number of species in any country, the species of these genera have more than the average number of varieties. In large genera the species are apt to be closely, but unequally, allied together, forming little clusters round other species. Species very closely allied to other species apparently have restricted ranges. In all these respects the species of large genera present a strong analogy with varieties. And we can clearly understand these analogies, if species once existed as varieties, and thus originated; whereas, these analogies are utterly inexplicable if species are independent creations. (Darwin 1872, p. 47 emphasis added)

The section was entitled "Summary," but Darwin did more than merely summarize the material. He introduced a new idea that would be a fundamental theme of Origin: the failure of the doctrine of independent creation as important evidence. This was no mere summary but a powerful new argument. The species fall into a pattern that (i) makes sense if they arose from what were once varieties but (ii) makes no sense on the view of special creation. That second clause makes the argument powerful. Without it, the evidence is merely consistent with his theory-Darwin would have had spent almost fifty pages for a mere "we can clearly understand these analogies" on his theory. That is not much of a payoff. However, with the theological interpretation, his theory becomes compelling.

My second example deals with the problem of classification of the species. Nineteenthcentury biology was strongly influenced by the larger-than-life eighteenth-century Swedish botanist Carl Von Linné, or Linnaeus. In Systema Naturæ, Linnaeus had presented his hierarchical method of classification which envisioned the species falling into groups called genera, genera falling into groups called families, families grouped into orders, orders grouped into classes, and so forth. Linnaeus was famous worldwide, and his classification system was universally accepted. Deus creavit, Linnaeus disposuit (God created, Linnaeus organized) was his less than humble, self-appointed station in life. However, Darwin contradicted Linnaeus, arguing (again in a chapter summary, this time from Chapter 4) that the idea of God creating such a pattern was untenable:

The several subordinate groups in any class cannot be ranked in a single file, but seem clustered round points, and these round other points, and so on in almost endless cycles. If species had been independently created, no explanation would have been possible of this kind of classification. (Darwin 1872, p. 104 emphasis added)

By the end of the book, Darwin was even more emboldened: "This grand fact of the grouping of all organic beings under what is called the Natural System, is utterly inexplicable on the theory of creation." (Darwin 1872, p. 413 emphasis added) Darwin was, of course, aware that the well-known Linnaean classification had not previously been found to be theologically problematic as he was now claiming it to be. Certainly not with the great Linnaeus. What then did Darwin know that had escaped Linnaeus? What discovery led Darwin to such an important and crucial claim? Darwin gave no further explanation or justification. It simply was a bare theological assertion. However, it was epistemologically important because it made evidence extremely powerful that otherwise was of limited value. The value was limited because well-known exceptions to the pattern-namely, similar designs in otherwise distant species-would neutralize any positive claims. In other words, if Darwin were to claim the Linnaean hierarchy as a hard prediction of his theory, he then would have to contend with these so-called analogies which violated the prediction. As it was, Darwin addressed analogies, such as the "wondrous" electric organs that were found in distant fish species, in his discussion of difficulties with the theory. Darwin was forced to admit that evolution could have it both ways:

As two men have sometimes independently hit on the same invention, so in the several foregoing cases it appears that natural selection, working for the good of each being, and taking advantage of all favourable variations, has produced 
similar organs, as far as function is concerned, in distinct organic beings, which owe none of their structure in common to inheritance from a common progenitor (Darwin 1872, p. 152)

In other words, when the species' designs fell into the Linnaean hierarchy, evolution could explain it, and when they did not fall into the Linnaean hierarchy, evolution also could explain it. Darwin could cast the analogies as "superficial," but nonetheless, they weakened the positive argument. Darwin's claim that the evidence refuted creation was far more powerful but entailed a theological claim.

My third example is from biogeography, a subject that Darwin treated extensively. Several of his theological findings dealt with islands, such as the presence of unique bat species on various islands which otherwise were home to no other terrestrial mammals:

Such cases as the presence of peculiar species of bats on oceanic islands and the absence of all other terrestrial mammals, are facts utterly inexplicable on the theory of independent acts of creation. (Darwin 1872, p. 419 emphasis added)

Darwin's favored explanation, dispersal following by adaptation (Darwin 1872, p. 351), reminds us of the hard dichotomy Darwin was drawing. Either the species were absolutely fixed (another doctrine inherited from Linnaeus, although Linnaeus softened it later in life) or creation is falsified. This coupled with the strong aversion to anything resembling a deus ex machina, such as the creator installing unique bat species on an island somewhere in the middle of the ocean, meant the failure of creation. In other words, if the choice was between (i) trans-oceanic bat migration followed by adaptation to their new home and (ii) special creation of unique bat species on various islands around the world, the former easily wins out because the latter implies a deus ex machina, and since the former refutes the fixity of species, creation is refuted. It was a powerful argument but soaking in theology at every turn. Remove the theology, and the argument collapses. This same framework is also implicit in Darwin's interpretation of the finches and other species found on the Galapagos Islands (Hunter 2001, pp. 61-62).

These three examples illustrate the important role of theology in Darwin's evidence and arguments. Darwin repeatedly made bold theological claims about a wide range of biological categories, including variation, heredity, biogeography, anatomy, behavior, and classification. (Hunter 2014) Using Darwin's language from (Darwin 1872) but paraphrasing for brevity, Darwin found the following observations contradicted the ordinary view of independent creation:

Hybrids, produced by crossing distant species within a genus, may resemble, in some ways, other species of the genus. (130-31) Individuals are sometimes reproductively sterile. (422) Blind cave-animals share affinities with other inhabitants of the same continent rather than with blind cave-animals in other continents. (110-11) Species on volcanic islands, hundreds of miles from a continent, may be similar to the inhabitants of that continent. $(322,354)$ Species have a close relationship with other species inhabiting distant lands. (334) Species introduced by man into a region sometimes exterminate native species. (347-48) Whole orders of animals, such as Batrachians (frogs, toads, newts), are absent on oceanic islands which, otherwise, are favorable environments for them. (350) Lower organisms range more widely than the higher organisms. (359) For a given species, that part of the structure that differs from the same part in other species of the same genus is more variable than those parts that are closely alike in the several species. (122) Nature has so much variety yet so little real novelty. (156) The habits and structure of some animals are not in agreement. There are upland geese with webbed feet which rarely go near the water, and no one except Audubon has seen the frigate-bird, which has all its four toes webbed, alight on the surface of the ocean. (142) The similar bones in the arm of the monkey, in the foreleg of the horse, in the wing of the bat, and in the flipper of the seal are clearly not of special use to these animals. (160) Trifling characters that prevail throughout many and different species, especially those having very different habits of life, have high value in species classification. (372-73) Specific characters, or those by which the species of the same genus differ from each other, are more variable than generic characters in which they 
all agree. For instance, the color of a flower is more likely to vary in any one species of a genus if the other species possess differently colored flowers than if all possessed the same colored flowers. (415-16) A part developed in a very unusual manner in one species alone of a genus, and therefore, as we may naturally infer, of great importance to that species, is eminently liable to variation. (416) All the parts and organs of many species are commonly linked together by graduated steps. Nature never takes a sudden leap from structure to structure. (156) We never find, for instance, the bones of the arm and forearm, or of the thigh and leg, transposed. (382) Organs frequently bear the plain stamp of inutility, such as the teeth in the embryonic calf or the shriveled wings under the soldered wing-covers of many beetles. (420)

All of these arguments are theological because, as with my first three examples above, they hinge on premises about what a creator would and would not do regarding creation of the world. While there is a long history, in previous centuries, of such claims (Hunter 2014), Darwin was taking the argument to greater levels of detail. In this sense, Darwin was forging new ground. He had discovered, beneath a patina of beauty and complexity, a vast underworld of disutility and dysteleology. Practically every aspect of the organic world, when scrutinized in detail, was yet another theological signpost, indicating the absence of mindful construction and therefore requiring blind secondary causation. However, it all hinged on a particular theological tradition. We may rightfully ask, why exactly is it true that the lower organisms ranging more widely than the higher organisms goes against divine intent? Or again, why should we expect to find bones of the arm and forearm, or of the thigh and leg, sometimes transposed? Any answer would require a theological response far more detailed and sophisticated than Darwin was prepared to provide. Nonetheless, there was no hiding it. In his summary of Chapter 6, for instance, Darwin explained the importance of theology to his overall thesis:

We have in this chapter discussed some of the difficulties and objections which may be urged against the theory. Many of them are serious; but I think that in the discussion light has been thrown on several facts, which on the belief of independent acts of creation are utterly obscure. (Darwin 1872, p. 164 emphasis added)

In dealing with the many evidential problems, it was the theology that saved the theory. Darwin provided lengthy discussions of the science, but in the end, it was theology that provided strong evidence. Researchers have long since noted that Darwin's strong arguments for evolution had a peculiar structure. Rather than present compelling positive evidence for his theory, these arguments were contrastive, providing support for his theory by virtue of rebuking an alternative.

Paul Nelson has shown that Darwin's arguments for evolution from imperfection and homology are both deeply theological and epistemologically important. (Nelson 1996) Elliott Sober has shown how it is precisely these contrastive arguments that make evolution so compelling. Not by increasing the probability evolution is true but by significantly reducing the probability of the alternative. So important is this mode of argument that Sober has characterized it as Darwin's Principle. Sober has investigated Darwin's arguments in detail (Sober 1999, 2008, 2009). The reasoning has the form of a likelihood ratio that compares two hypotheses by computing the ratio of the conditional probabilities of an observation given the respective hypotheses. As the above examples from the Origin illustrate, the likelihood ratio favors evolution by arguing that the evidence contradicts the ordinary view of independent creation. In other words, at their core, Darwin's arguments incorporated theological assumptions. (Hunter 2014)

For Darwin, these were the crucial proof of evolution, and they were independent of evolutionary mechanisms, such as natural selection. This was the conclusion of Kenneth Waters who pointed out that natural selection did not play a dominant role in Darwin's powerful arguments for evolution. Instead, these arguments focused on patterns. (Waters 2009, p. 137) Waters observed that "in many discussions, natural selection is not an essential part of his view. That is, it was not doing the explanatory work in his reasoning. ... Natural selection can be read out of many of Darwin's arguments about the superiority of his 'view' 
compared to the alternative of independent creation." (Waters 2009, p. 133) Indeed, in some evidence, such as the lack of eyes in cave fish, Darwin explicitly ruled out natural selection as a cause.

Similarly, Dilley perceptively argued that "Darwin utilized positiva theology in order to help justify (and inform) descent with modification and to attack special creation." (Dilley 2012, p. 47) Chris Cosans has observed that "Throughout the Origin, he [Darwin] usually contrasts his account not with that of other evolutionists such as Lamarck or Chambers, but with that of someone we would now call a 'special creationist."' (Cosans 2005, p. 364)

The point here is that these contrastive arguments were important for Darwin and they were theological. These arguments were not merely sidebar points but crucial in making the powerful, compelling interpretations of the evidence.

\section{Darwin Was Merely Practicing Reductio Theology in the Origin}

Another view of Darwin's use of theology is that he merely was practicing reductio theology. That is, he was merely testing the opposing, ordinary view of special creation to evaluate its assumptions in light of the empirical evidence. Under the reductio model, the theological claims made by Darwin do not reflect (i) Darwin's personal religious beliefs or (ii) any theological dependencies of his theory of evolution. In other words, the reductio model cleanly separates and decouples the substantial theological content of Darwin's writings from his theory of evolution. In this model, Darwin and later evolutionists can make significant theological assertions without forfeiting the scientific status of evolution because their theological assertions are tangential and merely in service of addressing theological views held by others. Otherwise, Darwin's theological assertions were dispensable.

However, this defense fails on both counts. As we saw in Section 3, Darwin was testing various narrow theological claims about the biological world, which had not been proposed by earlier natural theologians. The Linnaean classification example was particularly noteworthy given that the renowned Linnaeus had clearly stated the exact opposite- that God created the species according to the classification system he proposedof what Darwin claimed. In many of the other examples, Darwin claimed that so much evidence was inexplicable on special creation where, in fact, no such expectations had ever been stated. Darwin was not merely testing an existing theory of creation; he was arguing from his own theory of creation.

Second, Darwin's theological claims were indeed very much incorporated by his theory. Darwin himself stated this in Chapter 6 of the Origin when he explained that his theory hinged on the utilitarian doctrine "that every detail of structure has been produced for the good of its possessor." (Darwin 1859, p. 199) This idea that every detail of structure serves a utilitarian, functional need ruled out non-material categories, such as beauty, delight, and order. It is true that utilitarian ideas were important in British natural theology, but the natural theologians also held up non-material categories as evidence for design. (Hunter 2021) Darwin, on the other hand, was firmly committed to a strictly utilitarian doctrine:

The foregoing remarks lead me to say a few words on the protest lately made by some naturalists, against the utilitarian doctrine that every detail of structure has been produced for the good of its possessor. They believe that very many structures have been created for beauty in the eyes of man, or for mere variety. This doctrine, if true, would be absolutely fatal to my theory. (Darwin 1859, p. 199)

Here Darwin expressed a requirement of the utilitarian design doctrine. Non-utilitarian explanations that had been considered-that structures have been created for beauty in the eyes of man, for mere variety, or to delight man or the Creator (this last item was added in the sixth edition)—would be "absolutely fatal" to Darwin's theory. Darwin then pivoted into a passage that argued forcefully that in nature utilitarian design is not observed.

Thus, we can hardly believe that the webbed feet of the upland goose or of the frigate-bird are of special use to these birds; we cannot believe that the same 
bones in the arm of the monkey, in the fore leg of the horse, in the wing of the bat, and in the flipper of the seal, are of special use to these animals. We may safely attribute these structures to inheritance. (Darwin 1859, pp. 199-200)

Not only are many designs not perfect, but they are also not even useful. Therefore, they must have been inherited in a descent with modification process. It was an unapologetic argument from utilitarian design, and it was powerful. For who could believe an all-powerful creator would engage in such miscues? However, it was a theological argument. Darwin's theory entailed the utilitarian design doctrine. (Hunter 2021) If God created the world, it must be in accord with utilitarian design principles. The alternative-that structures may be created for beauty, variety, or delight-was unacceptable. Darwin, in his own words, tells us not only that his theory hinges on theological claims, but he also tells us precisely what the underlying theology is. Darwin clearly was not merely practicing reductio theology.

\section{In Spite of Epistemological Assistance from Theology, Darwin Had Epistemologically Sufficient Scientific Arguments and Evidence}

According to some, even if Darwin made theological arguments to support his theory, he nonetheless presented compelling evidence for his theory. In other words, if we strip out all of the theological claims and arguments, we are still left with a powerful, convincing set of scientific evidence and arguments that evolution, with its natural selection mechanism, could produce nature's complex structures. As a typical textbook entry informs the student, "Then, in 1859, the English naturalist Charles Darwin ... published convincing evidence that species evolve, and he proposed a reasonable mechanism explaining how evolution occurs." (Johnson and Peter 2004, p. 276) Beyond textbook orthodoxy, this view can be found in contemporary scholarship as well. John Hedley Brooke wrote that "Darwin's theory of evolution by natural selection ... showed how nature could counterfeit design ... giving rise to new and well-adapted species having all the appearance of design." (Brooke 2002, p. 171 emphasis added) Similarly, regarding natural selection, Robert Richards wrote that in the Origin Darwin made "its truth obvious." (Richards 2008, p. 48) Michael Ruse wrote, "Pure Paley is also no longer possible in light of Darwinian evolution; natural selection rules out the necessity of an appeal to an intervening God." (Ruse 2003, p. 331) Finally, science writer Carl Zimmer explained, "As a young man Darwin had admired Paley, but now he showed how natural designs could come into being without a designer's direct control." (Zimmer 2001, p. 49 emphasis added)

However, Darwin made no such demonstration, nor did he claim to have done so. Regarding natural theology's favorite example, the eye, in the Origin, Darwin presented a caveated thought experiment which he ended on a conciliatory note: "I have felt the difficulty far too keenly to be surprised at any degree of hesitation in extending the principle of natural selection to such startling lengths." (Darwin 1859, p. 188) Elsewhere Darwin's claims of how natural selection could produce complex structures were no stronger. For the serial homologies (similarities within a species, rather than across different species), for example, Darwin made what was a common argument in the Origin: that they were inexplicable on the ordinary view of creation because they provided no particular utilitarian benefit. Nonetheless, the most positivistic claim Darwin could muster was that "On the theory of natural selection, we can satisfactorily answer these questions." (Darwin 1859, p. 437) However, even this was too confident, and by the sixth edition, Darwin downgraded "satisfactorily" to "to a certain extent":

On the theory of natural selection, we can, to a certain extent, answer these questions. (Darwin 1872, p. 384)

Darwin was not the only one cautious about such claims. Readers were not left with such a conclusion either. There were harsh critics such as the eminent John Herschel. Herschel was by no means adverse to a naturalistic origin of the species, but he was unimpressed with Darwin's attempt, labeling it the "Law of Higgeldy-piggeldy." (Desmond and Moore 1991, p. 485) Furthermore, such skepticism was not limited to opponents. Many 
who accepted the idea of evolution nonetheless did not accept natural selection. By the end of the century, this contrast between (i) the acceptance of Darwinism and (ii) the lack of demonstration of how complex structures actually evolved was becoming clear. As William Bateson wrote:

In what follows it will be assumed that the Doctrine of Descent is true. It should be admitted from the first that the truth of the doctrine has never been proved. There is nevertheless a great balance of evidence in its favour, but it finds its support not so much in direct observation as in the difficulty of forming any alternative hypothesis. The Theory of Descent involves and asserts that all living things are genetically connected, and this principle is at least not contrary to observation; while any alternative hypothesis involves the idea of Separate Creation which by common consent is now recognized as absurd. In favor of the Doctrine of Common Descent there is a balance of evidence; it is besides accepted by most naturalists; lastly if it is not true we can get no further with the problem; but inasmuch as it is unproven it is right that we should explicitly recognize that it is in part an assumption and that we have adopted it as a postulate. (Bateson 1894, p. 4 emphasis added)

Bateson echoed Darwin's theological arguments. Evolution had not been proved or demonstrated in a positive sense. The most that Bateson could summon was that Darwin's theory of descent was "at least not contrary to observation." Nonetheless, it was the clear winner, for the alternative hypothesis of "Separate Creation" was clearly "absurd." What was succeeding was not Darwin's mechanism of natural selection but his theological perspective. Natural selection remained controversial well into the twentieth century (Bowler 2003, pp. 196, 224, 275, 325, 347; Gayon 2009, p. 286ff), but those questioning it, such as Bateson (Sarkar 2007, p. 55), generally agreed with the overarching Darwinian doctrine that falsified special creation.

As further evidence that Darwin lacked epistemologically sufficient scientific arguments and evidence, it is instructive to examine his summary defense in response to the question of whether common descent is universal, provided close to the end of the book. (Darwin 1872, p. 424) Cosans has perceptively pointed out that, though Darwin lacked evidence for universal common descent, his theory needed it to remain relevant and that it "can be traced back to speculations he had made on theology during the 1830s." (Cosans 2005, p. 365) In response to this hypothetical question of whether common descent is universal, which Darwin posed to himself, and as a summary of the best evidence he could muster for descent, Darwin provided five pieces of evidence that he felt carried the "greatest weight":

1. "All the members of whole classes are connected together by a chain of affinities, and all can be classed on the same principle, in groups subordinate to groups."

2. "Fossil remains sometimes tend to fill up very wide intervals between existing orders."

3. "Organs in a rudimentary condition plainly show that an early progenitor had the organ in a fully developed condition; and this in some cases implies an enormous amount of modification in the descendants."

4. "Throughout whole classes various structures are formed on the same pattern,"

5. " "and at a very early age the embryos closely resemble each other."

These five pieces of evidence clearly fail to achieve what Darwin intended. I discussed evidence 1 and 4 in Sections 3 and 4, respectively. They are theologically laden, and without the theology, in Dilley's words, "little substance remains." (Dilley 2012, p. 42) For evidence 2, as Steven Stanley has pointed out, Darwin departed from Baconian induction and instead appealed to future, yet undiscovered, fossils. (Stanley 1981) Darwin's qualifiers ("sometimes tend" to) reveal the weakness of the evidence, which at best amount to avoidance of a falsifier. If the fossil remains merely "sometimes tend to fill up very wide intervals," that means they sometimes fail to do so. This means Darwin lacked the evidence he needed and so appealed to future discoveries in the fossil record. 
For evidence 3, Darwin relied heavily on the argument from the so-called rudimentary structures, but this argument fails badly. (Hunter 2001, pp. 31-33) Darwin used the term "rudimentary" with high frequency. It appears in 101 instances in the sixth edition. The general idea is that a structure becomes "rudimentary" as it decays or shrinks due to lack of need and use. However, measuring need and use of a biological structure is notoriously difficult. Consider this claim:

The webbed feet of the upland goose may be said to have become almost rudimentary in function, though not in structure. In the frigate-bird, the deeply scooped membrane between the toes shows that structure has begun to change. (Darwin 1872, p. 143)

Here Darwin argued that the upland goose and frigate-bird rarely if ever are near water and therefore do not need the membranes between their toes which otherwise aid the birds when in water. He noted that the frigate-bird membrane is deeply scooped (i.e., reduced), indicating "that structure has begun to change." However, Darwin lacked the science to support any of this because he would need accurate measures of need and use. For instance, perhaps the birds use the membranes in occasional forays into water, or perhaps the membranes are of use in rare flooding conditions. On the other hand, perhaps the membranes serve some other need that arises away from water. This is no mere academic conjecture as evolutionary theory has a long history of failed claims of disutility-structures that were assumed to be of little or no use were later discovered indeed to have an unanticipated function. (Hunter 2001, p. 32)

Finally, even if Darwin were to overcome these problems with his claim, the evidence would mean very little without, again, a theological interpretation. The issue here is that the reduction or loss of a structure-if Darwin could indeed establish such an event—by itself provides no scientific support for evolution and common descent. Darwin's challenge is to show how his proposed process can create complex structures, not diminish or eliminate them. There is nothing about a reduction in the membrane between the toes of the frigatebird that mandates or indicates the origin of the species by natural selection or common descent. Indeed, Darwin even admits that natural selection is not needed in proposed rudimentary structure examples, such as the eyes of moles and of some burrowing rodents. (Darwin 1872, p. 110) Darwin holds this category of evidence out triumphantly because it defeats the fixity of species doctrine. Here again, we are back to religion.

Finally, evidence 5, the embryology evidence, is another important argument for Darwin. Words beginning with "embryo" appear 123 times in the sixth edition. The idea here is that, in the early stages of development, the embryos of different species resemble each other, and Darwin believes this demonstrates a shared common ancestor. Darwin places this evidence in the same sentence with evidence 4 as they share the same structure. Both pieces of evidence entail the utilitarian doctrine, namely, if God created the world, it must be in accord with utilitarian design principles, which we saw in Section 4. As with the homologies of evidence 4, it will be important for Darwin to show these embryonic similarities are not functionally required, which he attempts to do earlier in the book:

The points of structure, in which the embryos of widely different animals within the same class resemble each other, often have no direct relation to their conditions of existence. We cannot, for instance, suppose that in the embryos of the vertebrata the peculiar loop-like courses of the arteries near the branchial slits are related to similar conditions,-in the young mammal which is nourished in the womb of its mother, in the egg of the bird which is hatched in a nest, and in the spawn of a frog under water. We have no more reason to believe in such a relation, than we have to believe that the similar bones in the hand of a man, wing of a bat, and fin of a porpoise, are related to similar conditions of life. No one supposes that the stripes on the whelp of a lion, or the spots on the young blackbird, are of any use to these animals. (Darwin 1872, p. 388) 
Darwin's point here is that there are similarities in the embryos of widely different animals that are not functionally required. This is a crucial claim for his argument, and he continues to reinforce it with the observation that there are embryonic structures that are intricately adapted to their immediate functional needs.

To summarize the argument: we know that embryonic structures can be precisely adapted to their functional needs, but at certain early embryonic stages, there are homologous structures - similar across a wide range of animals - that do not appear to be precisely adapted to the functional need because their environments vary significantly. This argument has the same structure as the evidence 4 argument, and Darwin points this out in the above quote. He states that we have no more reason to believe that these homologous embryonic structures are adapted to the functional need "than we have to believe that the similar bones in the hand of a man, wing of a bat, and fin of a porpoise, are related to similar conditions of life." In other words, this is yet another application of the utilitarian design doctrine that we saw in Section 4, and once again, we are back to religion. Strip out the premise that if God created the world, it must be in accord with utilitarian design principles, and "little substance remains." (Dilley 2012, p. 42)

The view that the theology in Darwin's writings is, ultimately, incidental because Darwin has epistemologically sufficient scientific arguments and evidence for his theory fails badly. Darwin did not show how nature could counterfeit design, as Brooke claimed above. He did not make natural selection's truth obvious, as Richards claimed. Darwin did not have such scientific evidence. It is not that we merely must read a bit further, and look a little harder, within the vast tome of the Origin, and we will inevitably find a solid foundation of scientific confirmations. In fact, on natural selection, Darwin's own language was conciliatory, and on common descent, he admitted to multiple origins: "I believe that animals are descended from at most only four or five progenitors, and plants from an equal or lesser number." (Darwin 1872, p. 424) Finally, of the five categories of evidence that Darwin presents in closing as providing the "greatest weight" for common descent, one is weak and the other four are theologically laden and are left with little substance without the theological claims.

\section{In Spite of Its Theological Foundation, Evolutionary Science after Darwin Had No Such Metaphysical Dependence}

Another rebuttal is that, in spite of Darwin's theological foundation, including its epistemological importance, evolutionary science after Darwin, and certainly well into the twentieth century, contained no such metaphysical dependencies. In other words, if theology was initially important in Darwin's development of the theory, it was transient and theological mandates waned over time. However, this view too is contradicted by the literature. For example, a study of 32 textbooks at the undergraduate as well as high school levels found that a variety of theological claims were pervasive in the presentation of evidence for evolution (Dilley and Nicholas 2019). These theological claims were consistent and often identical to those made by Darwin.

Nor is this trend limited to textbooks. Darwin characterized Origin as "one long argument," and, after Darwin, later evolutionists continued the argument. Their later works sometimes included new scientific findings, but the structure of the arguments was unchanged. As one example, a typical argument is from the evidence of disutility and the interpretation of disutility as disproving design and therefore confirming evolution. Table 2 lists a sampling of quotes from leading post-Darwin works, presenting disutility examples specifically as evidence for evolution. In these examples, the authors are concerned with confirming evolution. These examples illustrate how Darwin's appeal to disutility has been canonized in the evolution literature. 
Table 2. A sampling of disutility arguments for evolution from post-Darwin works.

\begin{tabular}{|c|c|}
\hline Year & Example Quote \\
\hline 1891 & $\begin{array}{l}\text { If whales were made at once out of hand as we now see them, is it conceivable that } \\
\text { these useless teeth would have been given them? (Le Conte 1891, p. 180) }\end{array}$ \\
\hline 1923 & $\begin{array}{l}\text { This fact [of vestigial structures] has no meaning on the hypothesis of special } \\
\text { creation, while on the hypothesis of descent with modification it finds a satisfactory } \\
\text { explanation. (Lane 1923, p. 32) }\end{array}$ \\
\hline 1952 & $\begin{array}{l}\text { Nature is not in the habit of producing useless structures, hence we can explain } \\
\text { them only as vessels which once were useful and have not been completely } \\
\text { eliminated from the developmental sequence. (Lindsey 1952, p. 115) }\end{array}$ \\
\hline 1973 & $\begin{array}{l}\text { but what a senseless operation it would have been, on God's part, to fabricate a } \\
\text { multitude of species ex nihilo and then let most of them die out! (Dobzhansky 1973, } \\
\text { pp. 126-7) }\end{array}$ \\
\hline 1982 & $\begin{array}{l}\text { But if we look further, we find that the bones of the flightless dodo and penguin are } \\
\text { also hollow, as if adapted for flight; and that the mole and the cave salamander also } \\
\text { have a lens and retina that serve no function. Every organism has such vestiges of } \\
\text { structures that can only be the useless remnants of past adaptations. Why should we } \\
\text { have wisdom teeth, unless our jaws have become shorter, so that our ancestors' } \\
\text { teeth no longer fit? Why should we, like other primates but unlike almost all other } \\
\text { vertebrates, require vitamin C in our diet, unless we stem from ancestors who got } \\
\text { enough vitamin C in their diet of fruit? Do we find here evidence of wise design? } \\
\text { (Futuyma 1982, pp. 198-9) }\end{array}$ \\
\hline
\end{tabular}

Any engineer would naturally assume that the photocells would point towards the light, with their wires leading backwards towards the brain. He would laugh at any suggestion that the photocells might point away from the light, with their wires departing on the side nearest the light. Yet this is exactly what happens in all vertebrate retinas. Each photocell is, in effect, wired in backwards, with its write

1987 sticking out on the side nearest the light. The wire has to travel over the surface of the retina, to a point where it dives through a hole in the retina (the so-called "blind spot") to join the optic nerve. This means that the light, instead of being granted an unrestricted passage to the photocells, has to pass through a forest of connecting wires, presumably suffering at least some attenuation and distortion (actually probably not much but, still, it is the principle of the thing that would offend any tidy-minded engineer!). (Dawkins 1987, p. 93)

1991 There is no good explanation for the existence of useless rudimentary organs in the doctrine of creationism. (Grant 1991, p. 14)

However, there are some homologies that do look positively disadvantageous. One of the cranial nerves goes from the brain to the larynx via a tube near the heart. In fish this is a direct route. But the same nerve in all species follows the same route, and in the giraffe it results in an absurd detour down and up the neck, so that the giraffe has to grow maybe 3-5 meters more nerve than it would with a direct connection. The "recurrent laryngeal nerve," as it is called, is surely inefficient. It is easy to explain such an efficiency if giraffes have evolved in small stages from a fish-like ancestor; but why giraffes should have such a nerve if they originated independently ... well, we can leave that to others to try to explain. (Ridley 1993, p. 50, ellipsis in original)

1997 We are in fact plagued with dysfunctional design features from head to toe ... (Williams 1997, p. 134)

Careful studies of the mammalian fossil record show that the average length of time a species survives after its first appearance is around 2 million years. Two million years of existence, and then extinction. The story is similar for insects (average

1999 species duration: 3.6 million years) and for marine invertebrates (average species duration: 3.4 million years). In simple terms, this designer just can't get it right the first time. Nothing he designs is able to make it over the long term. (Miller 1999, p. 102) 
Table 2. Cont.

\begin{tabular}{ll}
\hline Year & \multicolumn{1}{c}{ Example Quote } \\
\hline & One of nature's worst designs is shown by the recurrent laryngeal nerve of \\
mammals. Running from the brain to the larynx, this nerve helps us speak and \\
swallow. The curious thing is that it is much longer than it needs to be ... In giraffes \\
the nerve takes a similar path, but one that runs all the way down that long neck \\
and back up again: a distance fifteen feet longer than the direct route! ... This \\
circuitous path of the recurrent laryngeal nerve is not only poor design, but might \\
even be maladaptive. That extra length makes it more prone to injury. It can, for \\
example, be damaged by a blow to the chest, making it hard to talk or swallow. But \\
the pathway makes sense when we understand how the recurrent laryngeal nerve \\
evolved ... But the particular bad designs that we see make sense only if they \\
evolved from features of earlier ancestors. If a designer did have discernable \\
motives when creating species, one of them must surely have been to fool biologists \\
by making organisms look as though they evolved. (Coyne 2009, pp. 82-85) \\
In a nutshell, the underlying design of the whole mitochondrial operation seems to \\
make no (theo)logical sense. Not only is the overall design of mtDNA \\
suboptimal-it is downright ludicrous ... However, as discussed in chapter 1, in \\
this book we are not particularly concerned with genomic features that suggest good \\
workmanship because such features are philosophically consistent with either \\
natural selection or intelligent causation. Our focus instead is on genomic features \\
that defy notions of a supreme intelligence underlying biological design. Genomic \\
flaws should in principle provide a more decisive test of whether unconscious \\
evolutionary processes or cognitive agents have shaped our genes. (Avise 2010, \\
pp. 104, 108)
\end{tabular}

All of these examples appeal to disutility just as Darwin had, and as in Darwin, the disutility evidence does not merely serve to rebuke design but rather serves as confirmation of evolution. The canonization of Darwin's argument from disutility was further illustrated in an exchange between evolutionists S. R. Scadding and Bruce G. Naylor. In 1981, Scadding argued that the disutility evidence did not support evolution. He noted the prevalence of the disutility argument: "In almost all biology textbooks that discuss the 'evidence for evolution,' vestigial organs are cited as one piece of evidence that supports evolutionary theory." (Scadding 1981, p. 173) Scadding then provided three problems with their use as evidence for evolution, as follows:

1. Claims of non-function in the past have been found to be false. Scadding cited Darwin, Wiedersheim, and Haeckel as sources of failed claims of non-function in human anatomy. Wiedersheim produced a list of 86 vestigial organs that Scadding found to be failed or uncertain, yet persisting in textbooks as evidence for evolution. (Wiedersheim's list was increased to 180 and submitted as evidence for evolution in The State of Tennessee v John Thomas Scopes trial of 1925.)

2. Claims of non-function are difficult or impossible to establish. Scadding pointed out that structures thought to be vestigial may provide function only on rare occasions and thus go unobserved. Furthermore, not only is any claim of non-function vulnerable to scientific progress, as were Wiedersheim's, but the argument makes evidence for evolution contingent on proving a negative.

3. Claims of non-function as evidence for evolution entail theological assumptions. Scadding was concerned that the strength of disutility arguments derived from the implicit or explicit attack on design or creationism and thus was theological: "I suspect that this argument gained widespread use not because it proves anything about evolution, but because it was thought to have particular force against some varieties of creationism." (Scadding 1981, p. 175)

Though Scadding concluded that vestigial organs "provide no evidence for evolutionary theory," (Scadding 1981, p. 173) Naylor flatly disagreed. He explained that disutility was an important line of evidence for Darwin and that it continues to be so: 
One of the more important lines of evidence used by Darwin to support his theory of evolution by means of natural selection concerned what he called "rudimentary, atrophied, or aborted organs." ... Regardless of how definitions are altered to suit particular arguments, the fact remains that the coccyx, ear muscles, and semilunar fold of the eye provide powerful suggestive evidence for the evolution of man from "lower" primates. (Naylor 1982, pp. 91-92)

Naylor rejected all three of Scadding's objections, as follows:

1. Vestigial organs need not be non-functional. Naylor agreed with Scadding that claims of non-function had a poor historical record and that most or all of Wiedersheim's examples in fact had some function. However, the finding of function by no means disqualified an organ from vestigial status, for new functions can evolve. This negated Scadding's assumption that vestigial organs must, by definition, be non-functional.

2. Non-functional organs and structures are obvious and compelling. The poor historical track record notwithstanding, and in spite of his argument that vestigial organs can be functional, Naylor provided several lists of structures that seem to be completely nonfunctional. In addition, while some hypothetical function, which may be discovered in the future, cannot be ruled out, any such appeal is to misunderstand the role of science. Science concludes what is probable and likely based on current evidence, not what an ingenious researcher may propose in the future.

3. Failures of special creation are automatically evidence for evolution. Naylor pointed out that Scadding's objection to theological arguments was inconsequential because "Evidence for evolution is automatically evidence against special creation," (Naylor 1982, p. 94) and vice versa.

The Scadding-Naylor interchange illustrates the continued assumption of theological utilitarianism (i.e., if God directly created the species they would be perfectly adapted with no signs of disutility) in confirmations of evolutionary theory. Darwin's disclaimerthat if the doctrine of utilitarian design is not true, it would be "absolutely fatal to my theory" - was no longer important, for theological utilitarianism was now an unspoken, de facto, given. For Naylor, evidence against special creation was, by definition, evidence for evolution. As Naylor explained:

Darwin relied heavily on vestigial organs to counter the theological "argument from design." Briefly stated, this latter proposal asserted that the occurrence of perfectly designed organisms necessitated the existence of a designer, obviously strong support for the creation myth of Genesis. However, Darwin was able to show that, in fact, organisms are often something less than perfectly created machines. The occurrence of variable and rudimentary organs indicated that plants and animals were produced by a tinker modifying, altering, and slowly removing pre-existing structures. It seems more reasonable to conclude that this tinker is natural selection rather than a god. Given the nature of the two explanations, any evidence in favor of one is necessarily against the other. (Naylor 1982, p. 94)

In other words, for Naylor, the assumption that a god would adhere to utilitarian design principles was not a particular theological position; it was simply a given. With this internalization of theological utilitarianism, Naylor was able to conclude, following Darwin, that the disutility evidence was powerful evidence for evolution:

I conclude, with Darwin, that rudimentary, atrophied, and aborted organs provide one of the more powerful evidences for the theory of evolution. They are readily explainable under the idea of descent with modification, indeed are an expectation of it, but very effectively indicate that the theory of special creation (and the argument from "design"), whatever its theological attributes, has been convincingly falsified scientifically. (Naylor 1982, p. 95)

Once again, the strength of the argument for evolution derives from the theological argument against special creation. Aside from rare dissenters such as Scadding, the 
argument from disutility and non-function has been prevalent in the literature. It is an example of how Darwin's theological appeals have continued in the evolution literature.

\section{Scientific Shortcomings of the Origin Were Eventually Remedied as Evolution Was Overwhelmingly Proven by the Later Science}

Another defense of Darwin's theological assertions is that, however much he and later evolutionists have relied on them, they ultimately became incidental as Darwin was proven correct by later science. Bowler's characterization of evolutionary theory coming of age by mid-century is representative:

With the consolidation of the evolutionary synthesis in the 1950s, the field had at last come of age. The broad outline of the history of life on earth was now known, and although more details might be revealed by the fossil record, few surprises were expected. The acrimonious debates of the early twentieth century between a range of mutually incompatible theories had been resolved by a broad consensus based on a revived Darwinism. Natural selection was the basic mechanism of evolution, and biologists had to work out the details of how that mechanism operated to produce the diversity of species we observe. (Bowler 2003, p. 347)

Here Bowler was not merely reporting on the emergence of a consensus view but on the truth value of that view. In its broad outline, the history of life on earth was "now known." There had been debates between the neo-Darwinists and other camps, such as the mutationists who emphasized the importance of novel mutations. However, with the coming of the modern evolutionary synthesis, the origin of species was "now known" to be the result of natural selection acting on random mutations. It is difficult to overstate the heights of this triumphant view. Consider this metaphysically laden passage from Nobel laureate Jacques Monod:

... chance alone is at the source of every innovation, of all creation in the biosphere. Pure chance, absolutely free but blind, at the very root of the stupendous edifice of evolution: this central concept of modern biology is no longer one among other possible or even conceivable hypotheses. It is today the sole conceivable hypothesis, the only one that squares with observed and tested fact. And nothing warrants the supposition-or the hope-that on this score our position is likely ever to be revised. (Monod 1971, pp. 112-13 emphasis in original)

Monod's high confidence is not the exception but the rule, as evolution is typically declared to be a fact, as certain as gravity, heliocentrism, or the sphericity of the earth. (Eldredge 1982, pp. 31-32) This triumphant tone is in contrast to empirical science which is not nearly so clear-cut. As Arlin Stoltzfus pointed out, the modern evolutionary synthesis view of biological variation being strictly random "has been breaking down from the moment it was proposed." (Stoltzfus 2021, p. 12) Specifically, the modern evolutionary synthesis viewed the species as originating from biological variation that is random with respect to need. Evolutionary direction was imposed externally by natural selection. In contrast to mutationism, the modern evolutionary synthesis drew a hard line at the boundary of the organism. Internal to the organism, change was supposed to be strictly unintelligent, without situational awareness, and blind to fitness considerations. It was random with respect to what mattered. External to the organism, on the other hand, directional, situation-appropriate change was supposed to be achieved by selection acting on the pool of random biological variation. Stoltzfus suggested non-empirical factors played a role elevating the importance of this "selection as the potter and variation as the clay" model:

Why did it become so important to associate mutation with randomness? ... the randomness doctrine proclaims a deeper mutation-is-unimportant doctrine in which variation is made subservient to selection ... In this way, the randomness doctrine provides a metaphysical guarantee of the classic dichotomy of selection and variation as the potter and the clay, that is, it differentiates selection, the 
source of order, shape, and direction, from mutation-not the source of those things, because it's "random." Patterns and interesting features and other orderly outcomes in evolution may be safely attributed to selection, because mutation is random. (Stoltzfus 2021, p. 7)

This "potter and clay" model was perfectly aligned with Darwin's theological arguments and conclusions against independent creation. As we have seen, Darwin made many non-empirical arguments requiring precisely what the modern evolutionary synthesis delivered: organisms that were strictly non-teleological. However, from an empirical perspective, the evolutionist's high confidence was not warranted, and subsequent findings have clearly established mutational bias. Organisms, from bacteria to plants and animals, produce mutations that are situation-appropriate-biased in a direction to assist the organism in the given conditions, and such bias influences the course of adaptation. (Stoltzfus 2021, p. 1)

The failure of its "potter and clay" model is only one of several scientific concerns with the modern evolutionary synthesis. For example, another core claim is that smallscale, adaptive evolutionary processes (i.e., microevolution) add up over time to produce large-scale evolutionary changes (i.e., macroevolution). (Simpson 1960) Simply put, microevolution is sufficient to explain macroevolution and the entire history of life. However, Douglas Erwin and others have reported that the disparate fields of paleontology, phylogenetics, and developmental biology all reveal patterns and discontinuities that "discredit any smooth extrapolation from allelic substitution to large-scale evolutionary patterns" (Erwin 2000, p. 78) and that "microevolution alone cannot explain macroevolution." (Reznick and Robert 2009, p. 841) In order to make progress in explaining the data, the modern evolutionary synthesis needed to release its grip. As Erwin put it, "Our understanding of evolution has become incomparably richer over the past few decades as the intellectual hegemony of population genetics has faded." (Erwin 2017, p. 12)

While it may sound good to have a "richer" theory, this has in fact resulted in substantially greater theory complexity to levels that far exceed normal parsimony limitations. The new approaches entail a far more complex set of mechanisms and processes, including potentiating mutations, (Erwin 2015) the evolution of the evolutionary process, (Erwin 2017) recruitment of gene regulatory networks, non-isotropic variation, shifts in the timing, rate, and place of gene expression, and multilevel species sorting. (Jablonski) Consider the theory complexity that is implied in merely the following summary of species sorting and emergence:

Species sorting-sometimes termed species selection in the broad sense, meaning differential origination and extinction owing to intrinsic biological propertiescan be split into strict-sense species selection, in which rate differentials are governed by emergent, species-level traits such as geographic range size, and effect macroevolution, in which rates are governed by organism-level traits such as body size; both processes can create hitchhiking effects, indirectly causing the proliferation or decline of other traits. Several methods can operationalize the concept of emergence, so that rigorous separation of these processes is increasingly feasible. A macroevolutionary tradeoff, underlain by the intrinsic traits that influence evolutionary dynamics, causes speciation and extinction rates to covary in many clades, resulting in evolutionary volatility of some clades and more subdued behavior of others; the few clades that break the tradeoff can achieve especially prolific diversification. (Jablonski 2017, p. 451)

It is difficult to keep track of the ever-increasing number of degrees of freedom in this evolutionary hypothesis. This high level of complexity is required to do what the modern evolutionary synthesis could not do-fit the data. However, such high levels of theory complexity raise serious questions of whether the theory is explaining the data or the data are explaining the theory.

The challenges faced by the modern evolutionary synthesis can also be seen in the resurrection of Lamarck who, in the space of only a few decades, went from being ignored 
and rejected for much of the second half of the twentieth century to a respected keyword. As one scientist put it, "When most biologists hear the name Lamarck or the term soft inheritance, the reaction is, 'Oh my God, here we go again,' ... The really heretical thing to say is that the environment could be pushing the epigenetic information in a direction that is beneficial." (Fitzpatrick 2006) Furthermore, as Denis Noble explained, "Lamarck and Lamarckian ideas were not only ignored but actively ridiculed during the second half of the 20th century." (Noble 2011)

The resurrection of Lamarck was mainly due to the increasing recognition of epigenetics toward the end of the century. As with mutation bias, epigenetics shows how adaptation can arise not by random mutation and natural selection as prescribed by the modern evolutionary synthesis but in direct response to environmental challenges. Adaptive change is observed to be environmentally induced in multiple individuals within a population, resulting in rapid change within a generation or so. In other words, adaptation mechanisms exist that (i) detect environmental challenges and (ii) implement changes within the organism that specifically respond to the detected challenges. As with mutational bias, epigenetics in a stroke hit at the very foundation of the modern evolutionary synthesis; presents a highly complex, multi-stage mechanism; harkens back to and resurrects the much-maligned Lamarck; and on top of all this, presents us with a real-life, observable, teleological element within biology. ${ }^{1}$

Consider a 2010 study that exposed yeast cells to a challenging environment. The yeast cells adapted, and the authors reported that "the adaptation was due to a response of many individual cells to the change in environment and not due to selection of rare advantageous phenotypes. The adaptation of numerous individual cells by heritable phenotypic switching in response to a challenge extends the common evolutionary framework and attests to the adaptive potential of regulatory circuits." (David et al. 2010, p. 131) These experimental results contradict the modern evolutionary synthesis view of how adaptive change comes about and how it propagates through the population.

In addition to these challenges, the core concept of universal common descent has also been challenged. As we saw in Section 3 above, Darwin knew the species did not always fall into a common descent pattern, but he viewed such cases as exceptions. One type of exception is the analogies, or convergence-striking similarities in otherwise distant species that must have evolved independently. In his 1871 critique of the Origin, St. George Jackson Mivart argued that convergence was a more serious problem than Darwin recognized:

On this theory [Darwinism] the chances are almost infinitely great against the independent accidental occurrence and preservation of two similar series of minute variations resulting in the independent development of two closely similar forms. (Mivart 1871, pp. 71-72)

While Mivart argued that there are "multitudes of examples" of convergence, he was aware of only a small fraction of the convergences that would later be discovered. Recently George McGhee has reported that convergence is "ubiquitous." Whereas Darwin concluded that evolution creates "endless forms most beautiful" (Darwin 1859, p. 490), in many cases, "evolution has produced the same form —or a very similar one-over and over again in many independent species lineages, repeatedly, on timescales of hundreds of millions of years." (McGhee 2011, p. xi). Simon Conway Morris has also showed the rather amazing level of convergence in biology, in contrast to the expected common descent pattern. (Morris 2005)

On the other hand, another surprising finding is divergence-striking differences in otherwise allied species-which could be said to be as ubiquitous as convergence. As with convergence, divergence also runs contrary to traditional views of common descent, where neighboring species, sharing a relatively recent common ancestor, should be highly similar. The prevalence of both convergence and divergence presents a challenge for common descent. Winston Ewert has reported that a dependency graph model performs far better than the common descent model when tested with large-scale genetic databases. Dependency graphs are an important construct in computer science. In complicated 
software applications, high-level software routines typically use a large set of lower-level software routines. The high-level routines are said to inherit the lower-level routines and have a dependency on those routines. Dependency graphs map out these relationships. The dependency graph indicates the different software modules that will be needed and how they are connected together. Ewert used dependency graphs to model the species character data and compared it to the common descent model. He used Bayesian model selection which accounts for both the model accuracy and the model parsimony, with nine different large-scale genetic databases, and found strong preferences for the dependency graph model in all cases. (Ewert 2018) This finding was a challenge to the common descent model, which evolutionists have consistently maintained to be the best model, in spite of the known, massive convergence and divergence in the character data.

These and other challenges have helped to spawn alternate views on the fundamental ways that evolution is supposed to work. There is, for example, Niles Eldredge's Hierarchy Theory of Evolution (HTE), the Constructive Neutral Evolution (CNE) theory, and the Extended Evolutionary Synthesis (EES). These alternate views are not minor adjustments, but rather represent significant changes to the modern evolutionary synthesis.

Stoltzfus characterized the "potter and clay" model of the modern evolutionary synthesis as a cancer that "must be attacked vigorously in all its manifestations." (Stoltzfus 2021, p. 2) He harkened back to the early twentieth century mutationists who "saw mutation as a difference-maker, as a potentially important source of initiative, creativity, direction, and discontinuity in evolution" and were rejected by the architects of the modern synthesis. (Stoltzfus 2021, p. 7) Similarly Noble states that the EES is not a refinement of the modern evolutionary synthesis but a replacement. (Mazur 2014)

This situation is reminiscent of the early twentieth-century debates between irreconcilable views. While these debates have, at times, been exaggerated, there nonetheless was a plurality of opposing views. (Largent 2009, p. 6) It is difficult to see how that is any different today. As a recent review paper reported, "Contemporary evolutionary biology comprises a plural landscape of multiple co-existent conceptual frameworks and strenuous voices that disagree on the nature and scope of evolutionary theory." (Fábregas-Tejeda and Francisco 2018, p. 127) Such a plurality of views and fundamental disagreements is hardly a sign that the field had at last "come of age" in the 1950s with the modern evolutionary synthesis and that with the coming of the modern evolutionary synthesis, the origin of species was "now known," as Bowler claimed.

Though there is vigorous disagreement on the science, all sides of the debate share the conviction that evolution, one way or another, occurred. Darwin's theological claims had convinced people that evolution had occurred, not how evolution occurred. Darwin's powerful themes, reviewed in the earlier sections above, were his religious arguments proving evolution to be true. Recall the passage from Bateson above explaining that the strength of the Doctrine of Descent was not from empirical science but from the abject failure of Separate Creation which, as Bateson explained, was "absurd." Gaps in Darwin's theory helped to fuel debates, involving Bateson and others. However, those debates should not be confused with dissension from Darwin's powerful religious themes proving evolution to be true. How evolution occurred was up for debate, but there was much greater concurrence that evolution, in one form or another, had occurred. (Gayon 2009, pp. 281-82) From its beginning, the modern evolutionary synthesis was challenged by the empirical evidence, but the theological components continued to provide the crucial confirmation that evolution was true. This can be seen in the apologetics literature, ranging from textbook chapters and technical articles to popular works, which argued for the veracity of evolution (Nelson 1996; Dilley and Nicholas 2019; Hunter 2020).

To summarize, leading mainstream experts in the life sciences hold to widely disparate theories of origins. Ever since Darwin (and before Darwin as well), debates between opposing, irreconcilable views have been the norm, not the exception. This state of affairs has prevailed because no single view has succeeded in explaining, and predicting, the empirical evidence. In particular, the modern evolutionary synthesis did not fulfill the high 
proclamations ascribed to it. The state of the science, since Darwin, does not give merit to the notion that, regardless of evolution's reliance on theological assertions, the theology is incidental because Darwin was proven correct by later science. In fact, evolutionary models have consistently failed on the science. The important support for Darwin's views remains his powerful theological arguments, not the empirical science.

\section{Conclusions}

Sections 2-7 in this paper address six rebuttals, respectively, to this paper's thesis. Section 2 demonstrates that Charles Darwin's development of his theory of evolution, beginning with natural selection in the fall of 1838, is aligned with his prior religious commitments. It is not the case that Darwin's scientific findings predated and influenced his religious beliefs. Those beliefs, simply put, favored a transcendent creator who used indirect means to create the world. While this is reminiscent of deism, the religious traditions that influenced Darwin and the culture around him are complex, and a robust treatment of them is beyond the scope of this paper. What is relevant for this paper's thesis is merely that Darwin's science followed his religion, not vice versa.

Section 3 shows the prevalence and importance of religion in Darwin's mature theory of evolution. In the Origin, theological premises played a crucial epistemological role. Furthermore, Section 4 explains that those theological premises were not merely serving a reductio theology role. The theological premises played a crucial positive role in justifying the theory. As Section 5 shows, the science alone was not sufficient to advance the theory. Indeed, there were major scientific challenges to the theory. Even in Darwin's summary arguments, he relied heavily on theological premises.

Section 6 demonstrates that this theological foundation is not peculiar to Darwin's writings. Rather, Darwin's use of a theological framework for interpreting empirical findings became a hallmark of the literature. Later evolutionists consistently employed remarkably similar, and often identical, arguments to justify the theory. In this sense, the Origin is more accurately viewed as initiating a genre in which religion provides the key interpretive filter to be applied to the scientific evidence.

Finally, Section 7 shows that, after Darwin, as with the theology, the science also followed suit. That is, just as Darwin faced significant scientific challenges, so did evolutionary theory after Darwin. This led to strenuous disagreements on core theoretical concepts. These disagreements did not dissipate with the modern evolutionary synthesis but rather have continued. There does not exist a single, scientifically compelling explanation for the origin of species. To summarize, these sections demonstrate the following six findings (Table 3):

Table 3. Findings.

\begin{tabular}{|c|c|}
\hline Section & Finding \\
\hline 2 & Darwin's discovery of transmutation followed from his prior religious influences. \\
\hline 3 & Darwin's theological premises in the Origin played a crucial epistemological role. \\
\hline 4 & $\begin{array}{l}\text { Darwin's theological premises played a positive role in justifying the theory and } \\
\text { were not merely practicing reductio theology. }\end{array}$ \\
\hline 5 & $\begin{array}{c}\text { Darwin lacked epistemologically sufficient scientific arguments and evidence for his } \\
\text { theory. }\end{array}$ \\
\hline 6 & The epistemological role of theology in evolutionary thought persisted after Darwin. \\
\hline 7 & $\begin{array}{l}\text { Scientific challenges for evolutionary theory also persisted after Darwin, resulting in } \\
\text { strenuous disagreements on core theoretical concepts. }\end{array}$ \\
\hline
\end{tabular}

Taken together, these six findings powerfully demonstrate the priority that religion has over science. Rather than a scientific theory, a more accurate model for evolution is that it is a theological research program. This is a step beyond contemporary scholarship. Historians 
have examined the religious aspects of evolution, including religious influences on Darwin, how he viewed his theory interacting with religion, the impact of evolution on religion, and so forth. (Brooke 1985, 2009; Cornell 1987; Richards 1997, 2008) According to these works, religion may have provided Darwin with key insights or otherwise aided him in formulating or developing his theory. However, the theory is not viewed as religious in a fundamental sense. Empirical evidence and non-theological concepts are seen as playing the central role in Darwin's science, and theology merely serves as a handmaiden or accomplice (Dilley 2012, pp. 55-6).

Nonetheless, beginning with Darwin, evolutionists have been clear about theology's foundational role. Consider Stephen Jay Gould's summary of the crucial role that theology played for Darwin:

Odd arrangements and funny solutions are the proof of evolution-paths that a sensible God would never tread but that a natural process, constrained by history, follows perforce. No one understood this better than Darwin. Ernst Mayr has shown how Darwin, in defending evolution, consistently turned to organic parts and geographic distributions that make the least sense. (Gould 1980, pp. 20-21)

Of course, making the "least sense" is not positive evidence of evolution. Evolution is envisioned to work according to natural selection causing improvements in fitness. Odd arrangements and funny solutions that make the least sense do not improve fitness-they are such powerful evidence for evolution by virtue of falsifying independent creation. However, as we have seen, such falsification entails theological assumptions.

Gould well summed up what we saw in the earlier sections above. Theology is epistemologically crucial to evolutionary theory. Theology mandates evolution in spite of the science. In this sense, evolution is a religious theory. Not because it cannot be tested, but because it is tested and nonetheless is held triumphantly. Evolution fails repeatedly on the empirical science, and yet it is held by consensus to be a fact.

The crucial role of theology in evolutionary theory is obvious. Ever since Darwin, evolutionary studies have seen a consistent history of (i) heated debates on core issues, (ii) proliferation of competing and contradictory theories, (iii) increasingly high complexity of those theories, (iv) failed predictions, (v) continued reliance on theological mandates, and (vi) high confidence in the theory. This suggests that theology plays an indispensable role and that the relationship between science and religion is more complex than is generally understood.

Funding: This research received no external funding.

Conflicts of Interest: The author declares no conflict of interest.

\section{Note}

Criticisms of epigenetics tend to rest on assumptions of the modern evolutionary synthesis. For instance, one criticism is that whatever the capabilities are of epigenetics, all of its structures and mechanisms must, in any case, have been originally due to random mutations and natural selection. As David Haig wrote, "How else could their purposefulness have originated except by natural selection of 'random' mutations?" (Haig 2007, p. 427)

\section{References}

Avise, John. 2010. Inside the Human Genome: A Case For Non-Intelligent Design. Oxford: Oxford University Press.

Bateson, William. 1894. Materials for the Study of Variation, Treated with Especial Regard to Discontinuity in the Origin of Species. London: Macmillan.

Bowler, Peter J. 2003. Evolution: The History of an Idea. Berkeley: University of California Press.

Brooke, John. 1985. The Relations between Darwin's Science and His Religion. In Darwinism and Divinity. Edited by John Durant. New York: Oxford University Press, pp. 40-75.

Brooke, John Hedley. 2002. Natural Theology. In Science \& Religion. Edited by Gary Ferngren. Baltimore: Johns Hopkins University Press.

Brooke, John. 2009. Laws Impressed on Matter by the Creator? In Cambridge Companion to the Origin of Species. Edited by Michael Ruse and Robert J. Richards. New York: Cambridge University Press, pp. 256-74. 
Coyne, Jerry. 2009. Why Evolution is True. New York: Viking.

Cornell, John. 1987. God's Magnificent Law: The Bad Influence of Theistic Metaphysics on Darwin's Estimation of Natural Selection. Journal of the History of Biology 20: 381-412. [CrossRef]

Cosans, Chris. 2005. Was Darwin a Creationist? Perspectives in Biology and Medicine 48: 362-71. [CrossRef] [PubMed]

Darwin, Charles. 1838. Notebook D: [Transmutation of species (7-10.1838)]. CUL-DAR123. Transcribed by Kees Rookmaaker. Available online: http:/ / darwin-online.org.uk/ (accessed on 26 August 2021).

Darwin, Charles. 1859. The Origin of Species, 1st ed. London: John Murray.

Darwin, Charles. 1872. The Origin of Species, 6th ed. London: John Murray.

David, Lior, Elad Stolovicki, Efrat Haziz, and Erez Braun. 2010. Inherited adaptation of genome-rewired cells in response to a challenging environment. HFSP Journal 4: 131-41. [CrossRef]

Dawkins, Richard. 1987. The Blind Watchmaker. London: W. W. Norton.

Desmond, Adrian, and James Moore. 1991. Darwin: The Life of a Tormented Evolutionist. New York: W. W. Norton.

Dilley, Stephen. 2012. Charles Darwin's use of theology in the Origin of Species. BJHS 45: 29-56. [CrossRef] [PubMed]

Dilley, Stephen. 2013. The Evolution of Methodological Naturalism in the Origin of Species. HOPOS: The Journal of the International Society for the History of Philosophy of Science 3: 20-58.

Dilley, Stephen, and Tafacory Nicholas. 2019. Damned if You Do and Damned if You Don't: The Problem of God-talk in Biology Textbooks. Communications of the Blyth Institute 1: 37-70. [CrossRef]

Dobzhansky, Theodosius. 1973. Nothing in Biology Makes Sense Except in the Light of Evolution. National Association of Biology Teachers 35: 125-29. [CrossRef]

Eldredge, Niles. 1982. The Monkey Business. New York: Washington Square.

Erwin, Douglas. 2000. Macroevolution is more than repeated rounds of microevolution. Evolution and Development 2: 78-84. [CrossRef]

Erwin, Douglas. 2015. Novelty and Innovation in the History of Life. Current Biology 25: R930-R940. [CrossRef]

Erwin, Douglas. 2017. Developmental push or environmental pull? The causes of macroevolutionary dynamics. History and Philosophy of the Life Sciences 39: 36. [CrossRef]

Ewert, Winston. 2018. The Dependency Graph of Life. BIO-Complexity 2018: 1-27. [CrossRef]

Fábregas-Tejeda, Alejandro, and Vergara-Silva Francisco. 2018. Hierarchy Theory of Evolution and the Extended Evolutionary Synthesis: Some Epistemic Bridges, Some Conceptual Rifts. Evolutionary Biology 45: 127-39. [CrossRef]

Fitzpatrick, Tony. 2006. Researcher Gives Hard thoughts on Soft Inheritance. In The Source. St. Louis: Washington University, August 3, Available online: https:/ / source.wustl.edu/2006/08/researcher-gives-hard-thoughts-on-soft-inheritance/ (accessed on 26 August 2021).

Futuyma, Douglas J. 1982. Science on Trial: The Case for Evolution. New York: Pantheon Books.

Gayon, Jean. 2009. From Darwin to today in evolutionary biology. In The Cambridge Companion to Darwin, 2nd ed. Edited by Jonathan Hodge and Gregory Radick. Cambridge: Cambridge University Press.

Gould, Stephen Jay. 1980. The Panda's Thumb. In The Panda's Thumb. New York: W. W. Norton and Company.

Grant, Verne. 1991. The Evolutionary Process, 2nd ed. New York: Columbia University Press.

Haig, David. 2007. Weismann Rules! OK? Epigenetics and the Lamarckian temptation. Biology and Philosophy 22: 415-28. [CrossRef]

Hunter, Cornelius. 2001. Darwin's God: Evolution and the Problem of Evil. Grand Rapids: Brazos.

Hunter, Cornelius. 2014. Darwin's Principle: The Use of Contrastive Reasoning in the Confirmation of Evolution. History of the Philosophy of Science 4: 106-49. [CrossRef]

Hunter, Cornelius. 2020. On the Influence of Religious Assumptions in Statistical Methods Used in Science. Religions 11: 656. [CrossRef]

Hunter, Cornelius. 2021. The Role of Non-Adaptive Design Doctrine in Evolutionary Thought. Religions 12: 282. [CrossRef]

Himmelfarb, Gertrude. 1959. Darwin and the Darwinian Revolution. New York: W. W. Norton.

Jablonski, David. 2017. Approaches to Macroevolution: 2. Sorting of Variation, Some Overarching Issues, and General Conclusions. Evolutionary Biology 44: 451-75. [CrossRef]

Jenkins, Bill. 2019. Evolution Before Darwin: Theories of the Transmutation of Species in Edinburgh, 1804-34. Edinburgh: Edinburgh University Press.

Johnson, George, and Raven Peter. 2004. Biology. New York: Holt, Rinehart and Winston.

Lane, Henry Higgins. 1923. Evolution and Christian Faith. Princeton: Princeton University Press.

Largent, Mark. 2009. The So-Called 'Eclipse of Darwinism'. In Descended from Darwin: Insights into American Evolutionary Studies. Edited by Joe Cain and Michael Ruse. Philadelphia: American Philosophical Society, pp. 1925-50.

Le Conte, Joseph. 1891. Evolution-Its Nature, Its Evidences, and iTs Relation to Religious Thought, 2nd ed. New York: D. Appleton.

Lindsey, Arthur W. 1952. Principles of Organic Evolution. St. Louis: C. V. Mosby.

Mandelbaum, Maurice. 1958. Darwin's Religious Views. Journal of the History of Ideas 19: 363-78. [CrossRef]

Mazur, Suzan. 2014. Replace the Modern Synthesis (Neo-Darwinism): An Interview with Denis Noble. Huffington Post. July 9. Available online: https://www.huffingtonpost.com/suzan-mazur/replace-the-modern-sythes_b_5284211.html (accessed on 26 August 2021).

McGhee, George. 2011. Convergent Evolution. Cambridge: MIT Press.

Mivart, St. George Jackson. 1871. On the Genesis of Species. London: Macmillan.

Miller, Kenneth R. 1999. Finding Darwin's God. New York: Cliff Street Books. 
Monod, Jacques. 1971. Chance E Necessity. New York: Vintage Books.

Morris, Simon C. 2005. Life's Solution: Inevitable Humans in a Lonely Universe. Cambridge: Cambridge University Press.

Naylor, Bruce. 1982. Vestigial Organs are Evidence of Evolution. Evolutionary Theory 6: 91-96.

Nelson, Paul. 1996. The Role of Theology in Current Evolutionary Reasoning. Biology and Philosophy 11: 493-17. [CrossRef]

Noble, Denis. 2011. Transformations of Lamarckism: From Subtle Fluids to Molecular Biology. Edited by Snait B. Gissis and Eva Jablonka. Cambridge: MIT Press.

Ospovat, Dov. 1981. The Development of Darwin's Theory: Natural History, Natural Theology, and Natural Selection. Cambridge: Cambridge University Press, pp. 1838-59.

Reiss, John O. 2009. Not by Design: Retiring Darwin's Watchmaker. Berkeley: University of California Press.

Reznick, David, and Ricklefs Robert. 2009. Darwin's bridge between microevolution and macroevolution. Nature 457: 837-42. [CrossRef] [PubMed]

Richards, Robert. 1997. The Theological Foundations of Darwin's Theory of Evolution. In Experiencing Nature. Edited by Paul H. Theerman and Karen Hunger Parshall. Dordrecht: Kluwer, pp. 61-79.

Richards, Robert. 2008. Darwin's Theory of Natural Selection and Its Moral Purpose. In The Cambridge Companion to the 'Origin of Species'. Edited by R. Richards and M. Ruse. Cambridge: Cambridge University Press, pp. 47-66.

Ridley, Mark. 1993. Evolution. Boston: Blackwell Scientific.

Ruse, Michael. 2003. Darwin and Design: Does Evolution Have a Purpose. Cambridge: Harvard University Press.

Sarkar, Sahotra. 2007. Haldane and the Emergence of Modern Evolutionary Theory. In The Handbook of the Philosophy of Science. Edited by Mohan Matthen and Christopher Stephens. Amsterdam: North-Holland.

Scadding, Steven R. 1981. Do Vestigial Organs Provide Evidence for Evolution? Evolutionary Theory 5: 173-76.

Simpson, George Gaylord. 1960. The history of life. In The Evolution of Life. Edited by Sol Tax. Chicago: University of Chicago Press.

Sober, Elliott. 1999. Modus Darwin. Biology and Philosophy 14: 253-78. [CrossRef]

Sober, Elliott. 2008. Evidence and Evolution: The Logic Behind the Science. Cambridge: Cambridge University Press.

Sober, Elliott. 2009. Did Darwin write the Origin backwards? Proceedings of the National Academy of Sciences 106: 10048-55. [CrossRef]

Stanley, Steven. 1981. New Evolutionary Timetable. New York: Basic Books.

Stoltzfus, Arlin. 2021. Mutation, Randomness, and Evolution. Oxford: Oxford University Press.

Waters, C. Kenneth. 2009. The arguments in the Origins of Species. In The Cambridge Companion to Darwin, 2nd ed. Edited by Jonathan Hodge and Gregory Radick. Cambridge: Cambridge University Press.

Williams, George C. 1997. The Pony Fish's Glow: And Other Clues to Plan and Purpose in Nature. New York: Basic Books.

Zimmer, Carl. 2001. Evolution: The Triumph of an Idea. New York: HarperCollins. 